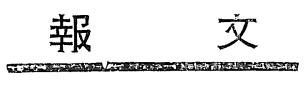

\title{
n-ドデシルベンゼンスルホン酸の界面化学的性状
}

$$
\text { 広 瀬 功* 三 雲 次 郎* }
$$

Surface-chemical Properties of $n$-Dodecylbenzene Sulphonic Acid

Isao Hirose, Jiro Mikumo

アルキルアリル（またはアルカリル）スルホン酸塩中 そは, 界面活性剂と乙て優秀なものが多く, 諸種の目的 飞応用されている。なかんづくアルキルベンゼンスルホ ン酸塩は，アルカリルスルホン酸塩としてはもちろん。 またあらゆる種類の合成活性戍中でる，その生産量が最 る多いを認められる。このるのは専らソーダ塩で, ソー 多塩としての性状関しては発表されたところが多い が，その基濋体である遊離酸てついては，それが油脂分

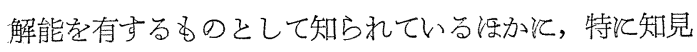
の発表されたるのが見当らないよらである。

そとで我々队との遊離酸としてn-ドデシルベンゼン モノスルホン酸を純䊉に合成して, 特に先の界面化学的 性状を研究し，併せてとれをそのソーダ塩と比較した。

\section{1. n-ドデシルベンゼンスルホン酸の合成}

純ラウリン酸 (融点 $44.3^{\circ} \mathrm{C}$, 中和価 280.5) を三塩化

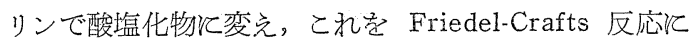
より $\left(\mathrm{AlCl}_{3}\right)$, ベンゼンと縮合させてラウロフェノン (融点 $45.2^{\circ} \mathrm{C}$ ) そし, 次飞亜鉛アマルガムと塩酸を用い て Clemmensen 還元とよつてとれをドデシルベンゼン (融点 $\left.-3^{\circ} \mathrm{C}, d_{4}^{20} 0.8594, n_{\mathrm{D}}^{20} 1.4862\right)$ 飞導いた。この ものを $10 \%$ 発慗硫酸㓅り 5 15ㄷ で処理してnード デシルベンゼンモノスルホン酸を得た。その硫黄含量 (理論值 9.82) は9.80 (中和谪定), 9.82 (Carius) で 純䊉と認められる。スルホン化物はエーテル抽出物を卜 ルエンから再結晶を反復して精製した。との一部を食塩 液沉よりソーダ塩とした。用いたアルキル基の鑽長と， スルホン化の条件等加ら見て, 生成物中のスルホン基は アルキル基汶し, 主として $p$ - 位汶あるものと認めら れる。

遊離酸ね若干咬湿性つ白色無定形固体で,ソーダ塩も 多少吸湿性を有する白色鱗片状結晶である。

* 名古屋大学工学部工業有機化学教室 (名古屋市千種 区不老町)

Depertment of Industrial Organic Chemistry, Faculty of Eugeneering, Nagoya University

\section{2. n-ドデシルベンゼンスルホン酸の性状}

溶解性 遊離酸は常温で水, アルコール, エーテルル 容易に溶解し，温めれね゙ベンゼン及びトルエンに溶解す る。トルエンは本物質の精製渓適で㐫る。

ソーダ塩は冷水にはほをえぞ溶解せず， $60^{\circ} \mathrm{C}$ 以上で 良く溶ける ${ }^{1)}$ 。従つてソーダ塩は水溶液から容易に精製 される。

市販アルキルベンゼンスルホン酸塩製品の有効成分中 のアルキル基の炭素数は平均約 12 と認められ，それは プロピレンホたはイソブチレンの接䪅重合による主とし てイソドデシレンマ基づくるのとされている。

nードデシルベンゼンスルホン酸ソーダが冷水飞難溶 性なのに反し，市販品の有效成分がかなり易溶性でめる のは，去のアルキル基が，ここ合成された単一の直鎻 物と異り，混合物であるほか、，そのいずれるが著しく 枝分れしていることに一つの原因があると思われる。

界面活性 水溶液の表面張力を $20^{\circ}$ 及び $60^{\circ} \mathrm{C}$ で, Traube の滴数計用いて測定した（図一1)。气の界面 活性は対応するアルキルスルホン酸或は硫酸エステルの アルカリ塩と劣るが相当高い。な敌アルカリルスルホ ン酸塩の中には，元の遊離酸の方が明か、界面活性の高 いるのがあるが2，本物質についてほ両者の間著しい 差を示さないが，遊離酸の方がわずか汇活性が大きい。

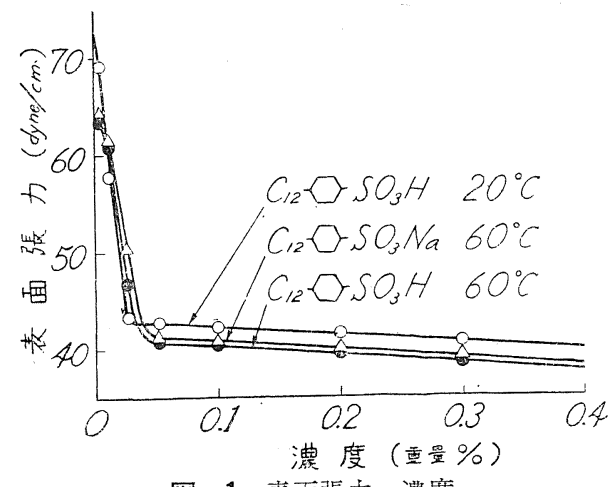

図一1 埊面張力一濃度 
電気伝導度 水溶液の比伝導度そ濃度との関係は, 実 測の結果から図一2汇示してある。図一3はこの実測值 加ら求的当量伝導度と濃度刀平方根との関係で㟧る。 遊離酸の伝導度は極めて高いが，同温度で測定された $n$ -

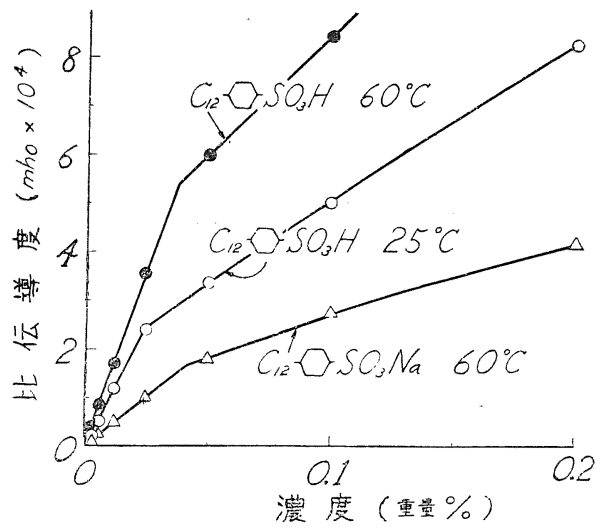

図一2 比伝導度一濃度

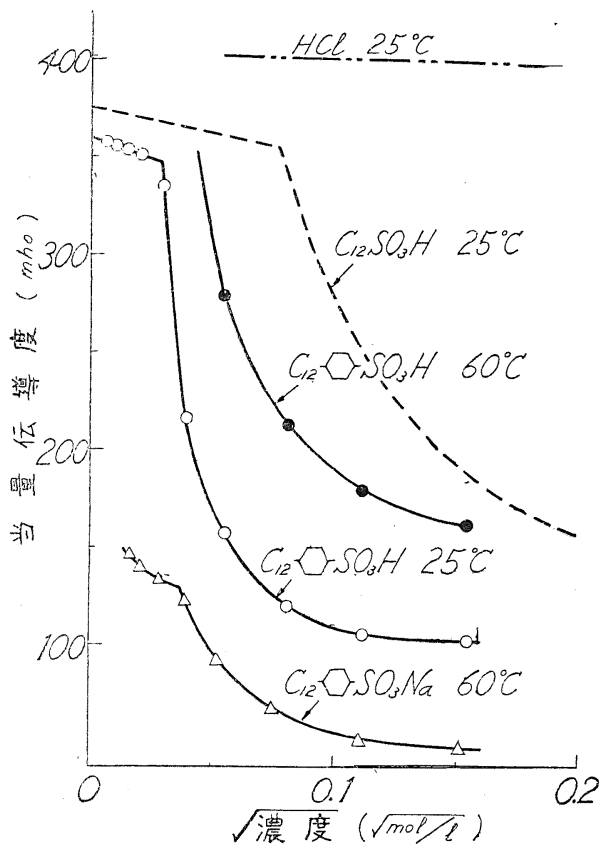

図一3 当量伝導度一浱度

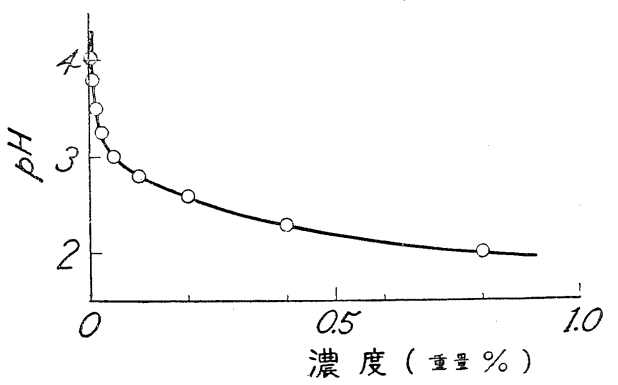

図一-4 $\mathrm{C}_{12}$-〈三 $-\mathrm{SO}_{3} \mathrm{H}$ の $\mathrm{pH}$ と莀度曲線 $\left(25^{\circ} \mathrm{C}\right)$
ドデシルスルホン酸の值よりは若干低い3)。

遊離酸はまたソーダ塩と同様に, コロイド電解質飞特 有な伝導度曲線を与光る。その曲線の屆折点恬それらの 物質分子のミセル形成の臨界濃度 c.m.c. 飞相当する。

そこで伝導度から求めた c.m.c. は

遊離酸, $25^{\circ} \mathrm{C} \quad 7 \times 10^{-4} \mathrm{~mol} / l(0.024 \%)$

$60^{\circ} \mathrm{C} \quad 1.2 \times 10^{-3} \mathrm{~mol} / l(0.038 \%)$

$\mathrm{Na}$ 塩 $60^{\circ} \mathrm{C} \quad 1.2 \times 10^{-3} \mathrm{~mol} / l(0.041 \%)$

そなり，それらの濃度は図一1 の表面張力一濃度曲線の 属曲点汇当るととろとょく一致する。

上得の結果を $n$-ドデシル基をるつ他種の界面活性剮!

の c.m.c. と比較すると

$$
\begin{array}{ll}
\text { ドデシルスルホン酸 } & 8 \times 10^{-3} \mathrm{~mol} / l\left(25^{\circ} \mathrm{C}\right) \\
\text { ドデシルスルホン酸 } \mathrm{Na} & 8 \times 10^{-3} \mathrm{~mol} / l\left(25^{\circ} \mathrm{C}\right) \\
\text { ドデシル硫酸 } \mathrm{Na} & 6 \times 10^{-3} \mathrm{~mol} / l\left(26^{\circ} \mathrm{C}\right)
\end{array}
$$

ドデシルアンモニウムクロリド $1 \times 10^{-2} \mathrm{~mol} / l$ (室温)

ラウリン酸 $\mathrm{Na} \quad 2.3 \sim 2.4 \times 10^{-2} \mathrm{~mol} / l\left(17 \sim 70^{\circ} \mathrm{C}\right)$ のいずれよりも著しく低く，

$$
\text { オレイン酸 }\left(\mathrm{C}_{18}\right) \mathrm{K} \quad 7 \sim 12 \times 10^{-4} \mathrm{~mol} / l\left(26^{\circ} \mathrm{C}\right)
$$

の場合に近い。このととから本物質のミセル形成傾向に 対し，そのアルキル基の大さ $\left(\mathrm{C}_{12}\right)$ のほかに，ベンゼン 核が大いに影響をもつているととが推定される。

遊離酸の当量伝導度は c.m.c. 以下の低濃度液では塩 酸に近い值を示し, 本酸が強酸で, 希薄葰では単イオン そして解離度が極めて高く，c.m.c. 以上の濃度では急 激にアニオン或は分子の聚合が発展する。

水素イオン濃度 遊離酸の $\mathrm{pH}$ (図一4) はをた本酸が 強酸であることを明示している。

\section{3. 総括}

長鎻状アルキル基をもつアルカリルスルホン酸の有機 酸として並びにとの界面化学的性状関する知見を得る ため，nードデシルベンゼンモノスルホン酸を純粋に合成 して，その性状をとのソーダ塩と対比して検討した。

ソーダ塩は常温水に難溶であるが遊離酸は極めて易溶 性である。遊離酸は多くの非極性有機溶剂にる温時かな りよく溶解する。電気伝導度, $\mathrm{pH}$ の測定により，遊離 酸は希薄浚では極めて強い酸性を有する。その臨界々セ ル濃度は対応するドデシル化合物炕比較して極めて低 く, 本酸はそのソーダ塩と共に典型的なコロイド電解質 である。その界面活性は相当高く，また遊離酸の方が ソーダ塩よりも活性がわずが沉大り。

本研究の要旨注炤和 28 年 11 月 8 日日本化学会東海 支部大会で発表した。

(昭和 28 年 12 月 23 日受理)

$$
\text { 交献 }
$$

1) 小川雅䓉，工化，54，780（昭26）

2) 後藤敏男 - 三雲次郎, 工化，55，387 (昭27)

3) McBain, Dye, Johnston, J. Am. Chem. Soc., 61, 3210 (1939) 